\title{
One Bloody Regime Change and Three Political Paradoxes. The Romanian Revolution of 1989 and Its Legacy
}

\author{
Dragoş Petrescu ${ }^{1}$
}

Recibido: 14 de junio de 2020 / Aceptado: 15 de julio 2020

\begin{abstract}
This study focuses on three political paradoxes which characterize the bloody 1989 regime change in Romania and the thirty-year period which elapsed, that is, 1989-2019. These three political paradoxes read as follows: Paradox \#1: The bloody anti-communist revolution of 1989 brought to power the second- and third-rank members of the communist power elite and a number of technocrats who had been close to the power structures of the defunct Romanian Communist Party (RCP); Paradox \#2: The number of registered victims after the collapse of the communist regime on 22 December 1989 surpasses the number of registered victims during the period 16-22 December 1989 by a ratio of about 7 to 1; and Paradox \#3: Although Romania went through one of the longest and most painful transitions to democracy in East-Central Europe (ECE), the country has not experienced so far an authoritarian backsliding after the year 2010 on the Central European model (especially the cases of Hungary and Poland). The present study addresses these paradoxes and explains why the violent collapse of the communist regime in Romania has led to the birth of a political culture of contestation, which prompted several waves of bottom=up mobilization in favor of democratic consolidation and, so far, hampered the rise of authoritarianism in this country.
\end{abstract}

Keywords: 1989 regime change; political violence; democratic consolidation; political paradox; authoritarian backsliding; political culture of contestation.

\section{[es] Un cambio de régimen sangriento y tres paradojas políticas. La revolución rumana de 1989 y su legado}

Resumen. Este estudio se centra en tres paradojas políticas que caracterizan el sangriento cambio de régimen de 1989 en Rumania y el período de treinta años que transcurrió, es decir, 1989-2019. Estas tres paradojas políticas dicen lo siguiente: Paradoja \# 1: La sangrienta revolución anticomunista de 1989 llevó al poder a los miembros de segundo y tercer rango de la élite del poder comunista y a varios tecnócratas que habían estado cerca de las estructuras de poder del difunto Partido Comunista Rumano (RCP); Paradoja \# 2: El número de víctimas registradas después del colapso del régimen comunista el 22 de diciembre de 1989 supera el número de víctimas registradas durante el período del 16 al 22 de diciembre de 1989 en una proporción de aproximadamente 7 a 1; y Paradoja \# 3: Aunque Rumania pasó por una de las transiciones más largas y dolorosas a la democracia en la Europa Centro-Oriental, el país no ha experimentado hasta ahora un retroceso autoritario después del año 2010 siguiendo el modelo centroeuropeo (especialmente los casos de Hungría y Polonia). El presente estudio aborda estas paradojas y explica por qué el colapso violento del régimen comunista en Rumania ha llevado al nacimiento de una cultura política de contestación, que provocó varias olas de movilización de abajo hacia arriba en favor de la consolidación democrática y, hasta ahora, obstaculizó el auge del autoritarismo en este país.

Palabras clave: Cambio de régimen de 1989; violencia política; consolidación democrática; paradoja política; retroceso autoritario; cultura política de contestación.

Faculty of Political Science, University of Bucharest (FSPUB)

E-mail: dragos.petrescu@unibuc.ro 
Sumario. 1. The 1989 Regime Changes in ECE: Outbreak, Unfolding and Outcome. 2. Romania, 1989-2019: A Contested Revolution and Its Legacy. 3. Concluding Remarks.

Cómo citar: Petrescu, D. (2020). One Bloody Regime Change and Three Political Paradoxes. The Romanian Revolution of 1989 and Its Legacy. Cuadernos de Historia Contemporánea, Vol. 42: 117-140.

The 1989 regime change in Romania was brief, violent and contested. What is generally referred to as the Romanian revolution of 1989 unfolded during the second half of the month of December 1989 and resulted in over 1,100 individuals dead and 3,300 wounded. Ironically, the revolutionary character of the only violent regime change in East-Central Europe (ECE) was heavily contested afterwards. ${ }^{2}$ A major ground for contestation was related to the high number of casualties recorded after the collapse of Nicolae Ceauşescu's dictatorship on 22 December 1989 at noon: of the total number of victims, over 850 were killed and 2,000 were wounded after 22 December. This study addresses three paradoxes which characterize Romania's Sonderweg to democracy over the thirty-year period which followed the regime change of 1989, that is, 1989-2019. These political paradoxes can be formulated as follows:

Paradox \#1: The bloody anti-communist revolution of 1989 brought to power the second- and third-rank members of the communist power elite and a number of technocrats who had been close to the power structures of the defunct Romanian Communist Party (RCP);

Paradox \#2: The number of registered victims after the collapse of the communist regime on 22 December 1989 surpasses the number of registered victims during the period 16-22 December 1989 by a ratio of about 7 to 1; and

Paradox \#3: Although Romania went through one of the longest and most painful transitions to democracy in ECE, the country has not experienced so far an authoritarian backsliding after the year 2010 on the Central European model (especially the cases of Hungary and Poland). ${ }^{3}$

These three paradoxes are discussed below. This article is structured on two parts. The first part provides useful background information concerning the 1989 regime changes in ECE, the overall problems of explanation posed by those events and the particular challenges one faces when addressing the Romanian case. The second part addresses the three political paradoxes mentioned above and analyzes the legacy of the violent 1989 regime change in Romania.

\section{The 1989 regime changes in ECE: Outbreak, unfolding and outcome}

The 1989 regime changes in ECE can be termed as revolutions. They were, however, revolutions of a particular kind because they were nonutopian, nonviolent and were

$2 \quad$ As Daniel Chirot aptly observes: "1989 was amazingly conflict free because the ruling elites did practically nothing to save communism. Yet what happened in Eastern Europe were real revolutions that upended entire economic and political orders that had been in place for four decades and had seemed, only a few years earlier, to be secure because of their effective repressive institutions." Daniel Chirot, You Say You Want a Revolution? Radical Idealism and Its Tragic Consequences (Princeton, NJ: Princeton University Press, 2020), 122.

3 The idea of three political paradoxes related to the 1989 regime change in Romania was put forward first in Dragoş Petrescu, "Blutige Revolution, paradoxe Folgen: Der Umsturz in Rumänien von 1989 und sein Erbe," Osteuropa (Berlin), No. 6-8 (2019), 93-104. 
not carried out in the name of a particular class. ${ }^{4}$ One exception did exist, nevertheless: in Romania, the revolutionary regime change was sudden and violent. In December 1989, in that country over 1,100 individuals were killed and some 3,300 were wounded. Three aspects - sequence, nature (negotiated or non-negotiated, violent or non-violent) and outcome of events - are crucial when one attempts at providing a causal explanation of the chain of events which brought down the communist dictatorships in ECE. As discussed elsewhere, this author contends that the collapse of the communist rule in ECE was provoked by an interplay of structural, conjunctural and nation-specific factors, which ultimately determined the sequence, and outcome nature of those events. ${ }^{5}$

Furthermore, in 1989 six communist dictatorships in ECE collapsed in the following order: Poland, Hungary, East Germany, Czechoslovakia, Bulgaria, and Romania. This particular order in which the six communist dictatorships broke down during the same year 1989 has been named by this author the 1989 sequence of collapse of the communist dictatorships in ECE. As mentioned above, this author contends that the 1989 revolutions in ECE were determined by a complex aggregation of structural, nation-specific and conjunctural factors. These factors operated and interacted with one another in various ways in each of the countries mentioned above, but they were definitely present in every case. ${ }^{6}$ This approach, the argument further reads, is able to accommodate issues of path dependence, patterns of compliance and contestation under communist rule and questions of interdependence at both international and Soviet Bloc levels. The particular way in which the three types of factors aggregated determined eventually the nature of the regime change in each of the six cases, that is, negotiated or non-negotiated, peaceful or violent, as well as the order in which the six communist dictatorships were overthrown.

This article concentrates on the political paradoxes associated with the outbreak, unfolding and outcome of the 1989 regime change in Romania, known as the "Romanian revolution of 1989." This author sets forth three key questions regarding the 1989 events in Romania and associates them with the three major aspects related to the regime changes of 1989 mentioned above, namely, sequence nature and outcome of events, as follows: (1) Sequence: why Romania occupies the last position within the 1989 sequence of collapse? (2) Nature: why the Romanian revolution was the only non-negotiated and violent of the 1989 revolutions in ECE? and (3) Outcome: why the bloody regime change in Romania brought the second-and third-rank communist officials to power and thus delayed the process of democratic consolidation?

As already mentioned, this author has explained the breakdown of the communist regime in Romania by examining the interplay of three types of factors: structural (common to all), nation-specific and conjunctural. ${ }^{7}$ In the following, I will address briefly the way these factors interacted with each other and provoked the regime

4 Shmuel N. Eisenstadt pointed to the peculiar features of the 1989 regime changes in ECE, which he associated with postmodernity, in "The Breakdown of Communist Regimes and the Vicissitudes of Modernity," Daedalus, Vol. 121, No. 2 (Spring 1992), 21-41.

5 Dragoş Petrescu, Entangled Revolutions: The Breakdown of the Communist Regimes in East-Central Europe (Bucharest: Editura Enciclopedică, 2014), 25-55.

6 Such an approach has been inspired by the path-breaking study by Ole Nørgaard and Steven L. Sampson, "Poland's Crisis and East European Socialism," Theory and Society, Vol. 13, No. 6 (November 1984), 773-801.

7 Dragoş Petrescu, Explaining the Romanian Revolution of 1989: Culture, Structure and Contingency (Bucharest: Editura Enciclopedică, 2010), 27-72. 
change in Romania. The first set of factors to be addressed are the "structural" factors, that is, those factors characteristic to all Soviet-type societies in ECE: economic decline and ideological decay. With regard to economic decline, a central issue is to assess the economic performance of the communist regime in Romania over the period 1945-89 in a broader regional and international context. This is important in order to illustrate the relationship between the severe economic crisis in the 1980s and the growing potential for social protest in 1989. Although Romania faced the most severe crisis among the six countries that experienced a regime change in 1989, that country was the last in a row to exit from communism that year. To explain such a paradoxical situation, one has to consider the mechanism of rising expectations and setbacks which characterized the Ceauşescu period (1965-89). After the takeover, the communist regime initiated a process of rapid industrialization which was accompanied by a civilizing process. These two processes, which went hand in hand from the mid-1950s to the mid-1970s resulted in a series of improvements concerning urban, particularly housing, development; spread of education and sanitation; transportation and increased mobility by the population during the 1960s and 1970s. The severe economic crisis of the 1980s paved the way for the bloody revolution of 1989. Due to the miseries of everyday life, the potential for protest among large strata of the population was particularly high in the late 1980s. This author argues that the period 1945-89 can be divided into four distinct periods which represent four distinct stages in the economic development of communist Romania. These stages also reflect the complicated relationship between politics and economics under communist rule in Romania. These four periods are: (1) humble imitation of the Soviet model, 1945-56; (2) development and emancipation, 1956-64; (3) closely-watched relaxation, 1964-81; and (4) crisis and decline, 1981-89. ${ }^{8}$

The period 1981-89 illustrates the close relationship between economic decline and the violent breakdown of the communist rule in Romania. To be sure, the severe economic crisis of the 1980s was among the main causes of the bloody regime change. During the 1980s, the developmental pattern imposed by the Ceauşescu regime continued to favor primary and secondary sectors with a strong emphasis on coal mining, steel, heavy machinery and petrochemical industries. While these sectors were unable to produce competitive goods for export, especially for western markets, their functioning required a high level of energy consumption, which led to a severe energy crisis in industry. Throughout the 1980s, instead of introducing economic reforms the regime imposed harsh rationing measures which affected primarily the population. These measures concentrated on the rationing of energy consumption (such as power supply for household use, gasoline for private cars etc.), food supplies (food rationing was introduced in the early 1980s) and basic consumer goods (such as soap, toothpaste, detergents etc.). Thus, by the late 1980s the mistaken economic policy of the Ceaussescu regime forced a large majority of the population to think in terms of biological survival. This economic policy, adamantly pursued by the Ceauşescu regime until its very end, led to both absolute and relative deprivation, which affected a great majority of the population and contributed significantly to the bloody demise of the communist rule.

8 On economic decline in communist Romania see Petrescu, Explaining the Romanian Revolution of 1989, 110 73. 
Ideological decay or the erosion of ideology was a phenomenon which the communist regimes in ECE experienced after Nikita S. Khrushchev delivered his "secret speech" at the Twentieth Congress of the Communist Party of the Soviet Union (CPSU) on the night of 24-25 February 1956. Marxism never appealed to the Romanian society, and the Stalinist terror unleashed after the communist takeover on 6 March 1945 did not contribute to an organic development of Marxist thought in Romania. After 1956, in an attempt to avoid de-Stalinization the Romanian communist power elite gradually made use of nationalism in order to secure popular support. Under the rule of Bicolae Ceauşescu, the communist power elite managed to turn Gheorghe Gheorghiu-Dej's cautious recourse to nationalism into a comprehensive nation-building process aimed at creating an ethnically homogenous "socialist nation" in Romania. In response to the Soviet-led invasion of Czechoslovakia by the Warsaw Treaty Organization (WTO) on the night of 20 to 21 August 1968, to which Romania did not participate, Ceauşescu delivered a public speech in which he condemned in clear terms the military intervention. As it turned out soon afterwards, Ceauşescu had nothing in common with the ideas and ideals of the Prague Spring. Nevertheless, Ceauşescu opposed the military intervention in Czechoslovakia because he was afraid that the independent-path policies pursued by the power elite in Bucharest beginning in 1964 could trigger at some point a similar Soviet-led WTO intervention. Ceauşescu's "balcony speech" of 21 August 1968 helped him gain widespread popular support. ${ }^{9}$ However, the deep economic crisis in the 1980 s and the new political situation in the Soviet Union after the coming to power of Mikhail S. Gorbachev prompted a rapid erosion of "Ceauşescuism," as an ideological substitute for Marxism-Leninism. After 1985, large segments of the Romanian society turned their hopes to Moscow: many believed that Gorbachev, the reformist leader in the Kremlin, would persuade Ceaussescu to introduce some reforms in order to improve their living standard. In this new context, independence from Moscow the cornerstone of the RCP legitimation strategy in the post-1968 period - ceased to appeal to a majority of the population. After the launch of Gorbachev's program of reforms, emancipation from the Soviet Union became irrelevant for large strata of the Romanian population. In the late 1980s, Moscow became synonymous with restructuring and openness, while the allegedly independent Romania was headed towards disaster. Thus, ideological decay - understood as the demise of Ceauşescu's national-communism as an ersatz ideology - contributed appreciably to the demise of the communist rule in Romania.

Contingency played a significant role in the collapse of the communist dictatorships in ECE. In the Romanian case, conjunctural factors proved to be even more influential. These factors are of two kinds, that is, external (exogeneous) and internal (endogeneous). Considering the power relations between Moscow and its European satellites, an external factor - which might be called the "Kremlin factor" - always influenced the decisions made by the power elites in Sovietized Europe. Until the mid-1980s, the "Kremlin factor" was synonymous with the intervention of Moscow

For a nuanced analysis of perceptions from below regarding Ceauşescu's gesture of defiance of August 1968 see Călin Goina, "Ceauşescu's Finest Hour? Memorializing Romanian Responses to the Warsaw Pact Invasion of Czechoslovakia," in Kevin McDermott and Matthew Stibbe, eds., Eastern Europe in 1968: Responses to the Prague Spring and Warsaw Pact Invasion (Cham, Switzerland: Palgrave Macmillan, 2018). 193-214. 
in the domestic affairs of the Sovietized countries in ECE. After Gorbachev's coming to power, the "Kremlin factor" evolved into the "Gorbachev factor."

The communist dictatorships in ECE proved to be particularly vulnerable to external conjunctural factors. Although there was no fixed set of external factors which one can identify to explain the six 1989 regime changes in ECE, one external factor was definitely present in all cases: the Gorbachev factor. ${ }^{10}$ Other factors were not present in all six cases. For instance, the Polish "negotiated revolution" initiated the "snowballing effect" which influenced to a large extent the demise of the communist regimes in Hungary, East Germany, Czechoslovakia, Bulgaria and Romania. ${ }^{11}$ The 1989 regime change in Poland, however, poses difficult problems of explanation exactly because a key external conjunctural factor, that is, the snowballing effect," was not present in the Polish case. In the case of Romania, two external conjunctural factors were of paramount importance: (1) the "Gorbachev factor;" and (2) the "snowballing effect." International media was another influential factor of the kind, which contributed in keeping alive or even developing a spirit of opposition towards the regime. Domestic conjuncture was equally relevant, although. the internal conjunctural factors contributed to a lesser extent to the breakdown of the Ceauşescu regime. In this respect, a significant internal conjunctural factor was the coming of age of the 1967-69 generation born of the policy of forced natality launched by Ceauşescu after his coming to power in March 1965.

Nation-specific factors determine the position each country occupies in the sequence of collapse of the communist dictatorships in ECE, as well as for the nature of the 1989 regime changes in the respective countries. To address these factors, one has to adopt a cultural approach to politics under communist rule and address the problem of political (sub)cultures at regime and community levels. ${ }^{12}$ In the case of Romania, these factors determined the position Romania occupies in the 1989 sequence of collapse, that is, the last in a row. Equally important, these factors determined the violent nature of the 1989 regime change in Romania, in contradistinction with the five nonviolent regime changes in ECE which preceded it. In this respect, the analysis focuses on the attitudinal and behavioral patterns which characterize the relationship between regime and society, and which emerged as result of successive transformations of the Stalinist model imposed on the Romanian society in the immediate aftermath of World War II. These transformations took place under certain constraints imposed by the Soviet policy towards the Sovietized countries in ECE in

10 Of the many works on the life and political career of Gorbachev see Moshe Lewin, The Gorbachev Phenomenon: A Historical Interpretation, new ed. (Berkeley, CA: University of California Press, 1991); Archie Brown, The Gorbachev Factor (Oxford: Oxford University Press, 1996); and William Taubman, Gorbachev: His Life and Times (New York: W. W. Norton \& Co, 2017). See also Mikhail Gorbachev and Zdeněk Mlynár, Conversations with Gorbachev: On Perestroika, the Prague Spring, and the Crossroads of Socialism, transl. by George Shriver (New York: Columbia University Press, 2002).

11 "Snowballing" is understood in the sense given by Samuel P. Huntington, The Third Wave: Democratization in the Late Twentieth Century (Norman, OK: University of Oklahoma Press, 1991), 33.

12 This author follows the distinction introduced by Kenneth Jowitt between elite, regime and community political cultures: (1) "elite political culture" is: "A set of informal adaptative (behavioral and attitudinal) postures that emerge as response to and consequence of a given elite's identity-forming experiences;" (2) "regime political culture" is: "A set of informal adaptative (behavioral and attitudinal) postures that emerge in response to the institutional definition of social, economic, and political life;" and (3) "community political culture" is: "A set of informal adaptative (behavioral and attitudinal) postures that emerge in response to the historical relationships between regime and community." Kenneth Jowitt, New World Disorder: The Leninist Extinction (Berkeley, CA: University of California Press, 1992), 55-56. 
the general Cold War context, of which the Brezhnev Doctrine was perhaps the most significant. This author has set forth above in the section dedicated to "structural" (common to all) factors a periodization of the communist period in Romania, which refers strictly to economic and social development.

Apart from this, one can identify five main periods which characterize the relationship between the communist regime and the Romanian society in general over the period 1945-89 in terms of repression, cooptation, compliance, dissent and open protest, as follows: (1) "revolution from above," 1945-56; (2) "community-building," 1956-64; (3) transition from "community-building" to nation-building, 196468; (4) fully-fledged nation-building, 1968-81; and (5) disenchantment, de-legitimation and open protest. 1981-89. Two key processes interacted permanently over these five periods. On the one hand, the regime adopted and applied consistently policies meant to tame and subsequently co-opt the population. On the other hand, the population reacted to these policies in various ways ranging from collaboration to open conflict with the regime. The attitudinal and behavioral patterns which resulted from the complex interaction of these processes ultimately determined the nature (violent) and timing (the last in a row) of the 1989 regime change in Romania.

One should stress once again the gradual transformation of the Stalinist mindset of the Romanian power elite over the period 1953 to 1968 , that is, from the death of Stalin to the refusal of the Brezhnev Doctrine. Over the said period, the political (sub)culture of the communist power elite went gradually through a series of transformations. In this respect, the year 1956 represented a watershed. The Stalinist power elite in Bucharest was not prepared to mitigate the devastating impact of Khrushchev's "secret speech" and consequently did not have a contingency plan for such a situation. When Khrushchev inaugurated his de-Stalinization campaign, Romanian Stalinists were obliged to devise an action plan meant to ensure their political survival and keep them in power. De-Stalinization as such gave the power elite in Bucharest enough reasons to feel insecure. Brought to power by the Red Army in the immediate aftermath of World War II, the Romanian communists, whose party never surpassed a membership of about 1,000 individuals, had a major legitimacy deficit. Thus, in order to remain in power Romanian communists had no other choice than to emulate the Stalinist model imported from the Soviet Union. Consequently, until the death of Stalin they were preoccupied to please the Kremlin, Sovietize their country and apply random terror in order to eradicate the opposition. Which they did with utmost cruelty.

De-Stalinization, however, changed dramatically the situation. Obviously, the Stalinist power elite in Bucharest had to avoid de-Stalinization. To emulate the post1956 political changes in Moscow would have meant, at best, to commit political suicide. What they did was to devise a disarmingly simple strategy of survival in four steps, which can be briefly defined as follows: (1) buy time; (2) fake the change; (3) take safe distance from Moscow; and (4) return to autochtonous values. By devising this simple action plan meant to keep it in power, the Stalinist power elite paved the way to Romanian national-communism. ${ }^{13}$ The first two steps were taken rapidly. First, Romanian communists delayed any major decision regarding de-Stalinization. Second, they declared that they had already engaged in de-Stalinization as early as

13 A path-breaking work on Romanian national-communism is Trond Gilberg, Nationalism and Communism in Romania: The Rise and Fall of Ceausescu's Personal Dictatorship (Boulder, CO: Westview Press, 1990). 
1952 when, as a result of the power struggle at the power elite level, top-ranking activists such as Ana Pauker, Vasile Luca and Teohari Georgescu were ousted from the party. ${ }^{14}$ The other two steps were more difficult to take, but contingency played a major role in this respect: two major events of 1956, the Polish October and the Hungarian Revolution, provided unexpected support to the action plan of the communist elite in Bucharest. The Hungarian Revolution (23 October - 4 November 1956), in particular, offered to the Romanian communists a unique opportunity to simulate total loyalty to Moscow and provide support to the Soviets to crush the revolutionary forces. Not long afterwards, in 1958, Khrushchev accepted to withdraw the Soviet troops from Romania. ${ }^{15}$ This permitted to the communist elite in Bucharest to accelerate the process of taking a safe distance from Moscow, which culminated with the so-called Declaration of April 1964. In brief, this official document proclaimed the right of each and every communist party to undertake its own path towards "building socialism."16

Simultaneously with taking a safe distance from Moscow, Gheorghiu-Dej and his inner circle of power initiated a process of "selective community-building." More precisely, they engaged in a process of creating new political meanings, shared by the ruling elite and the population, concerning the relationship between the communist party and society. One should stress once again the selective nature of the community building process launched in the aftermath of the 1956 events, because not all the segments of the Romanian society were allowed to take part in this process. ${ }^{17}$ Up to the year 1964, numerous Romanian citizens were imprisoned on political grounds while their offspring were denied basic civil rights. Obviously, they were considered "enemies of the people" and the community building process was not aimed at them. But de-Stalinization was a threat to Gheorghiu-Dej and his close collaborators, and a return to the people as the ultimate source of legitimacy was the only solution at hand. Gheorghiu-Dej's return to autochtonous values and recourse to party-state building in the guise of "selective community-building" created the basis for Ceauşescu's program of party-state building in the form of an all-embracing nation-building project.

Arguably, monolithism of the Party and emancipation from Moscow, as key features of the political culture of Romanian communism, are largely responsible for the violent nature of the 1989 regime change in Romania. Factionalism was seen as a "mortal sin," and a cleavage between hardliners and softliners never occurred at the top of the communist party. The most notable anti-Ceauşescu protest from within the ranks of top activists, the so-called nomenklatura, occurred very late, that is, in March 1989. On 14 March 1989, an open letter signed by six former high-rank

14 Ana Pauker was definitely the most influential political figure among those ousted in 1952. On Pauker's life and political career see Robert Levy, Ana Pauker, The Rise and Fall of a Jewish Communist (Berkeley, CA: University of California Press, 2001).

15 On the presence of Soviet troops on the Romanian territory in the postwar period, see Sergiu Verona, Military Occupation and Diplomacy: Soviet Troops in Romania, 1944-1958 (Durham, NC: Duke University Press, 1992).

16 Declaraţie cu privire la poziţia Partidului Muncitoresc Român în problemele mişcării comuniste şi muncitoreşti internaţionale, adoptată de Plenara lărgită a C.C. al P.M.R. din aprilie 1964 (Bucharest: Editura Politică, 1964).

17 The concept of "selective community-building" has been coined by Jowitt. See Kenneth Jowitt, Revolutionary Breakthroughs and National Development: The Case of Romania, 1944-1965 (Berkeley, CA: University of California Press, 1971), 74. 
officials of the party - Gheorghe Apostol, Alexandru Bârlădeanu, Silviu Brucan, Corneliu Mănescu, Constantin Pârvulescu and Grigore Răceanu - was broadcast by Radio Free Europe (RFE). The letter was addressed to Ceauşescu and represented basically an indictment of his mistaken policies. It was for the first time in communist Romania that former top party officials were publicly criticizing Ceauşescu's policies. The "letter of the six" marked a watershed in the history of the RCP because it represented the first major split at the level of the RCP elite. For the first time since the 1957 split at the top, that is, the Miron Constantinescu - Iosif Chişinevschi episode, the monolithism of the RCP was broken and a major faction of the nomenklatura openly protested against Ceauşescu's lead. At the same time, the signatories of the letter were already retired when RFE broadcast the text and their links with the Party were practically severed. In this respect, the letter came too late and therefore had an insignificant impact on RCP's domestic policies. In brief, the "mortal sin" of factionalism was committed too late to avoid a bloody regime change in December 1989.

As for the legitimating power of nationalism, after the coming to power of Gorbachev in 1985 the Ceauşescu regime was left with a sole target: the Hungarian minority in Romania. On 20 December 1989, when the city of Timişoara was already in the hands of the revolutionaries, Ceaussescu affirmed that the popular revolt in that city was the result of the activity of "hooligan elements, working together with reactionary, imperialistic, irredentist, chauvinistic circles ... aiming at the territorial dismemberment of Romania." Ceauşescu was hinting, among others, at neighboring Hungary and the Soviet Union. Nevertheless, the new image of the Soviet Union among Romania's population deeply undermined the propagandistic efforts of the regime. In the late 1980s, independence from Moscow ceased to be a major source of legitimacy for the communist regime in Romania. By 1989, the Romanian polity was definitely split into us and them. As for them - the inner circle of power around the Ceauşescu couple - they displayed a high level of cohesion, the highest among the six countries that compose the 1989 sequence of collapse, up to the very end of the regime. This explains in many respects why Romania occupies the last position, the sixth, in the said sequence. At the same time, to paraphrase the statement of a Romanian top communist official, independence ceased to be their legitimacy and this permitted popular protest to grow and spread across Romania in December 1989. It was because the RCP discourse centered on independence from Moscow lost its legitimating power in the eyes of a majority of the population that Romania was eventually able to exit from communism in 1989.

As for the community political culture, which has been termed as the political culture(s) of resistance, some authors argued that the failure of the Goma movement for human rights epitomizes the entire story of Romanian dissent. Speaking about the Romanian dissidence in the 1970s, a western specialist in East European affairs affirmed in the early 1980s that: "Romanian dissent lives in Paris and his name is Paul Goma." 18 This seems to be true since after Goma the other radical dissidents of the 1980s, such as Doina Cornea, Dorin Tudoran, Radu Filipescu, Gabriel Andree-

18 For Goma's own account of his dissent, see Paul Goma, Le Tremblement des hommes: Peut-on vivre en Roumanie aujourd'hui? trad. du roumain par Alain Paruit (Paris: Éditions du Seuil, 1979). On the meaning and legacy of the most important dissident action in communist Romania, see Cristina Petrescu, "The Goma Movement, Forty Years After: Controversies, Amnesia and (Mis)Canonization," Arhivele Totalitarismului (Bucharest), Nr. 3-4 (2017), 130-151. 
scu or Dan Petrescu, experienced a similar loneliness of radical dissidence. Group protests developed only slowly towards the end of the 1980s and replaced timidly the isolated dissident acts by courageous individuals. In November 1989, dissident Dan Petrescu initiated a campaign of collecting signatures against the reelection of Ceauşescu at the Fourteenth Congress of the RCP. Dan Petrescu, who was living in the Moldavian city of Iaşi, contacted Doina Cornea, who was living in the Transylvanian city of Cluj. It was for the first time when prominent dissidents organized a joint action against the regime. Another story, which is telling of the efforts and vacillations of the intellectuals who felt that they should do something to protest against the communist rule, is that of the "letter of the eighteen." It took a rather long time, that is, until mid-December 1989, to collect the signatures and send the letter abroad. Nevertheless, the fact that eighteen intellectuals eventually managed to become solidary in their protest in the autumn of 1989 indicates that something had changed by that time: a timid but shared feeling of solidarity was gradually replacing the "egoism of small groups." 19 Nevertheless, it was too late for a dissident movement to take shape and give birth to a political opposition able to fill the power vacuum in the afternoon of 22 December 1989. A few intellectuals, however, managed to speak to the large crowds gathered in the Palace Square in downtown Bucharest and argue convincingly that the monopoly of the RCP was over. In other words, they told the people that it was not about an anti-Ceauşescu uprising, but about an anti-Communist revolution. That moment marked the beginning of civil-society oriented opposition politics in Romania.

Considering the Polish experience and the birth of Solidarity in August 1980, a fundamental aspect of the political cultures of resistance refers to working-class unrest and the establishment of a cross-class alliance against the regime between rebellious workers and dissident intellectuals. In the Romanian case, this author distinguishes between settled workers and peasant-workers, and argues that distinct subcultures of resistance against the regime developed among these two categories of workers throughout the 1970s and 1980s. Settled workers severed their roots with countryside. They moved to towns seeking for a better-paid job and thus were dependent on the salary they received (usually in industry). By the end of 1980s, in the conditions of the severe crisis faced by the Ceauşescu regime, this category of workers was compelled to think in terms of biological survival and thus was more prone to engage in open protests. The economic crisis affected to a lesser extent the peasant-workers. During the period of severe food shortages 1981-89, such individuals were able to obtain from the plot of land they owned in their home villages agricultural products to feed their families and thus their potential for protest was lower. The peasant-worker is a good example of a strategy of the individual to survive in the conditions of severe economic crisis: a job in industry in the nearby town, and food supplies from the plot of land they owned in their home village.

Settled workers represented the most affected segment of society in the conditions of economic crisis. Beginning in the mid-1970s, four large and highly industrialized areas of communist Romania - the counties of Constanţa, Braşov, Hunedoara,

19 For an analysis of Romanian dissent in a Central European context, see Cristina Petrescu, "Eastern Europe, Central Europe or Europe? A Comparative Analysis of Central European Dissent and Romanian 'Resistance through Culture,"” in José M. Faraldo, Paulina Gulińska-Jurgiel and Christian Domnitz, eds., Europa im Ostblock: Vorstellungen und Diskurse 1945-1991 (Cologne: Böhlau Verlag, 2008), 231-49. 
and Timiş - attracted the largest number of internal migrants in the country, many of whom came from remote and less developed regions of Moldavia. In these areas, as the interregional long-distance migration figures show, came into being a relatively numerous class of workers relying only on the salary they received in industry - a class of settled workers. Between 1977 and 1989, the most important protests from below occurred in workplaces where settled workers constituted a majority: in the Jiu Valley (Hunedoara County) in 1977 and in Braşov (the capital of the Braşov County) in 1987. In the late 1980s there were in Romania four highly industrialized urban areas - the counties of Constanţa, Braşov, Hunedoara, and Timiş - where the number of workers coming from other regions of the country was particularly high. When the structural crisis deepened, it affected primarily the category of settled workers in those areas, who suffered from food shortages, strict rationing, and non-payment of wages. It is telling that in one of these four regions, that is, the Timiş County whose capital is Timişoara, it was sparked the Romanian revolution of $1989 .^{20}$

To conclude this section, it may be argued that while economic decline and ideological decay, in a particular window of opportunity, account for the collapse of Romanian communism in 1989. Political cultures, more precisely the political culture of Romanian communism and the political cultures of resistance account for the violent nature of the 1989 regime change in Romania and for last place this country occupies in the 1989 sequence of collapse of communist dictatorships in ECE. The analysis of attitudinal and behavioral patterns towards the communist regime developed during the Ceauşescu epoch (1965-89) and during the period spanning from the violent breakdown of the communist rule to the violent suppression of civil society protests in the University Square in Bucharest (December 1989 - June 1990) helps one explain the political paradoxes presented above. The next section will focus on these three political paradoxes.

\section{Romania, 1989-2019: A contested revolution and its legacy}

Paradox \#1: The bloody anti-communist revolution of 1989 brought to power the second-and third-rank members of the communist power elite and a number of technocrats who had been close to the power structures of the defunct Romanian Communist Party (RCP).

In the late 1980s, the dissatisfaction with the Ceauşescu regime was high among large strata of the population especially because of the daily humiliation and food shortage. Nevertheless, there were not many those who could foresee the swift demise of the regime in December 1989. Looking retrospectively, one can argue that the Romanian revolution of 1989 broke out unexpectedly, ensued violently and had an ambiguous outcome. Regarding its unexpected inception, one should stress that the 1989 revolution was sparked in the city of Timişoara, a multicultural and cosmopolitan urban center close to the western border of the country, and not in the capital city Bucharest. Thus, the Romanian case resembles the East German one consider-

20 For more on this, see Dragoş Petrescu "Commuting Villagers and Social Protest: Peasant-Workers and Working-Class Unrest in Romania, 1965-1989," in Sorin Radu and Cosmin Budeancă, eds., Countryside and Communism in Eastern Europe: Perceptions, Attitudes, Propaganda (Vienna: LIT Verlag, 2016), 497-524. 
ing that mass mobilization against the regime of the Socialist Unity Party of Germany (SED) was sparked by the peaceful religious protest of October 1989 in Leipzig, which spread to the rest of the country and eventually reached the capital city Berlin. With regard to the violent unfolding of the events in Romania, one should stress that this was due to the decision made by the communist power elite to suppress violently the peaceful protest in Timişoara before it reached other major urban centers in the country. Concerning the ambiguous outcome of the 1989 Romanian revolution, this refers to the fact that in spite of the large number of victims, more than 1,100 people dead and over 3,300 wounded. the first free elections of May 1990 brought to power the communist successor party, the National Salvation Front - NSF (Frontul Salvării Naţionale). The NSF gathered a large number of second- and third-rank communist officials and was headed by Ion Iliescu, a former member of the Central Committee (CC) of the RCP. These three fundamental phases of the 1989 regime change in Romania, that is, inception, unfolding and outcome, are addressed below in order to explain the Paradox \#1.

Inception. The 1989 revolution in Romania was sparked in the city of Timişoara during the night of 16 to 17 December. A peaceful religious protest by a small group of believers, in their majority of Hungarian ethnicity, contributes to the sparking of the revolution. The small group of believers was gathered around the house of Reverend László Tökés, a rebellious minister of the Protestant church, who was supposed to be forcibly evacuated from the house he occupied. The evacuation order was signed by the Oradea Diocesan, Bishop László Papp. The decision was prompted by Tökés' religious activism and his militant stance concerning the rights of the Hungarian minority in Romania. Such activities annoyed both the communist authorities and the leadership of the Protestant Church, and led to an open conflict between Tökés and Bishop Papp. ${ }^{21}$ Eventually, Tökés was released from the position he held in Timişoara and assigned to a new post in Mineu (Sălaj County), a small locality in Northern Transylvania. Tökés refused to leave the apartment he occupied in the parish house located in Timişoara on the Timotei Cipariu Street at No. 1, near the Maria Square. On 10 December 1989, after the Mass, Reverend Tökés announced that he was ordered to evacuate the parish house on 15 December and asked the churchgoers to come and witness his forced evacuation. ${ }^{22}$ As a consequence, on Friday, 15 December 1989, a small group of churchgoers gathered around the parish house in the Timotei Cipariu Street. On 15 December, the crowd in front of the parish house was composed mainly of members of the Hungarian minority who showed their support for their spiritual leader. There were around one hundred individuals in the front of the parish house. In the evening, at around 19:00 hours, some voices from the crowd began to sing "Deşteaptă-te române" (Awake thee, Romanian!), a song born of the 1848 revolution and considered a dissident song by the end of the rule of Ceauşescu. Many witnesses consider the moment when "Awake thee, Romanian!" was first

21 See Diocesan László Papp, "Scurtă caracterizare a preotului Tökés László,” dated 14 August 1989, in Marius Mioc, ed., Revoluţia, fãră mistere: Cazul László Tökés - Documente din arhiva Judecătoriei Timişora; Documente din arhiva parohiei reformate Timişoara; Mărturii (Timişoara: Editura “Almanahul Banatului," 2002), $144-45$.

22 Ibid., 19. See also Miodrag Milin, “Azi în Timişoara, mîine-n toată ţara!” in Timişoara: 16-22 Decembrie 1989 (Timişoara: Editura Facla, 1990), 46. 
sung in the Mary Square a crucial one. ${ }^{23}$ At the time, very few were able to grasp the real significance of the rapidly unfolding events. Tökés himself has confessed that his actions were not intended to provoke the downfall of the Ceaussescu regime: "I am ashamed of not having such a bold-spirited idea, all the more that the minority churches did not envisage such ideas. Our scope was to survive."24

On Saturday, 16 December, in the morning, the situation seemed to calm down, but in the afternoon people started to return to the place and a witness recalls that around 15:00 hours voices from the crowd shouted for the first time "Down with Ceauşescu!"25 By 17:00 hours, the square was packed with people and the traffic through the intersection became difficult. A small group started to sing "Hora Unirii" (The union round dance), the anthem of the 1859 union between Wallachia and Moldavia which set the foundation of the modern Romanian state. Looking retrospectively, numerous eyewitnesses stress the major importance of an apparently minor event. Around 19:00 hours, underground poet Ion Monoran performed an act of courage that would change the course of history: he pulled down the rope of the pantograph of a tram which was passing through the intersection and thus blocked the traffic. ${ }^{26}$ Moreover, Monoran urged the tram passengers to join the demonstrators in the Maria Square and raise their voices against the dictatorship. As many of those who knew him well have observed, Monoran had a predisposition to insubordination and a "taste for insurgency." In this respect, one must add that in high school Monoran attempted at fleeing the country by illegally crossing the border, was caught and severely punished. ${ }^{27}$ At the time when Monoran blocked the traffic, there were around 1,000 people in the Mary Square. From that moment on, history accelerated itself. People from the crowd started to shout slogans such as: "Freedom!", "Down with Ceauşescu!", and "Now, or never!" A column of around 1,000 people started to march towards downtown, while a group of some 200 believers remained in the front of Tökés' house. ${ }^{28}$ The demonstration against the forced evacuation of Reverend Tökés turned into an open protest against the Ceauşescu regime, increasingly joined by the population of Timişoara.

Unfolding. The first clashes between the protesters and repressive forces took place sporadically between 19:00 hours and 21:00 hours on Saturday, 16 December, while the crowds were slowly moving towards the Town Hall and the building of the RCP County Council. Practically, the revolution in Timişoara started on 16 December 1989 after 21:00 hours, when large groups of demonstrators began their march towards the city center. During the night of 16 to 17 December 1989, angered crowds wandered through the shadowy streets of Timişoara while riot police troops, military patrols, militia officers, and Securitate agents in plain clothes fought them, and oper-

23 Witness account by Daniel Vighi in Miodrag Milin, Timişoara în revoluţie şi după (Timişoara: Editura Marineasa, 1997), 27-28.

24 See “A Dialogue with László Tökés," interview by Marius Mioc (Timişoara, 2 November 2001), in Mioc, ed., Revoluţia, fără mistere, 77.

25 Witness account by Gazda Arpad in Marius Mioc, Revoluţia din Timişoara şi falsificatorii istoriei (Timişoara: Editura Sedona, 1999), 10.

26 Milin, Timişoara în revoluţie şi după, 24; see also note 5 at p. 205.

27 For more on the life and work of Monoran, see Cristina Petrescu and Cristian Valeriu Pătrăşconiu, Ion Monoran Private Collection, Courage Registry; http://cultural-opposition.eu/registry/?uri=http://courage.btk.mta.hu/ courage/individual/n10295; accessed on 8 July 2020.

28 Quoted in Milin, “Azi în Timişoara, mîine-n toată ţara!” 53 and 54. See also Ion Pitulescu, ed., Şase zile care au zguduit România: Ministerul de Interne în decembrie 1989 (Bucharest: n.p., 1995), 76. 
ated arrests. That night, around 180 individuals were arrested. ${ }^{29}$ Next day, Sunday 17 December in the morning, the city seemed calm, although the traces of the last night clashes could be seen all over the place. Militia and army troops were in control of the city center. Protesters, mainly young, shouting slogans such as "Freedom!" and "Down with Ceauşescu!" were nevertheless moving towards the same city center. Around 15:00 hours, the military adopted a more aggressive stance and attempted at dispersing the demonstrators. Soon after 16:00 hours on 17 December 1989 the first isolated shots were fired at the Timişoara protesters. The repression forces in Timişoara fired at the protesters before 17:00 hours on 17 December, when began the meeting of the Executive Political Committee of the CC of the RCP. During that meeting, Ceauşescu repeatedly demanded a swift and bloody repression of the protest: "I told you to shoot.... So, take immediate measures to liquidate quickly what happens in Timişoara." ${ }^{30}$ During the teleconference with the county Party secretaries, Ceauşescu referred to the events in Timişoara as an "attempt at an anti-socialist coup d'état." 31 Meanwhile, revolutionaries confronted the troops in the Opera Square in Timişoara. Night fell and suddenly systematic shooting began. Rapid machine gun fire was heard until 03:00 hours during the night of 17 to 18 December. Soon afterwards started pouring with rain for almost an hour - it was an unusually heavy rain for the month of December - and the machine gun fire ceased. The population in Timişoara was in shock: the communist authorities responded with deadly force to nonviolent protests by the population. Only later, after the fall of the Ceausescu regime, it was uncovered that during the night of 18 to 19 December the corpses of 40 protesters killed in Timişoara were sent to Bucharest to be cremated and the remains to be disposed of in order to cover-up evidence of the bloody repression. The corpses arrived in Bucharest on 19 December at 17:00 hours, and the cremation lasted until 20 December at 10:00 hours. ${ }^{32}$

Monday, 18 December 1989, the city was silent. The communist authorities were doing their best to wipe out the traces of the bloody repression. During the day, people walked quietly around the city. A large part of the city was on strike. A majority of the population could not believe what happened: they could not believe that the troops shot to kill. The situation remained unchanged during the next day, Tuesday, 19 December 1989. On Wednesday, 20 December, a column was formed and the demonstrators started their march towards the city center. At around 12:30 hours, the city was virtually in the hands of the protesters. The same day, Ceauşes$\mathrm{cu}$, who had just returned from an official visit to Iran, delivered a televised speech at 19:00 hours in which he announced that a state of emergency had been declared on the territory of Timiş county. In the meantime, protests by the population broke out at around 18:00 hours in the small town of Lugoj, situated some $60 \mathrm{~km}$ east of Timişoara. ${ }^{33}$

29 Reverend Tökés was forcibly evacuated from his house the same night of 16 to 17 December, during the interval 03:00-04:00 hours. Pitulescu, ed., Ministerul de Interne în decembrie 1989, 76.

30 See "Stenograma şedinţei Comitetului Politic Executiv al C.C. al P.C.R. din ziua de 17 decembrie 1989," in Pitulescu, 188-200.

31 Quoted in Pitulescu, 204.

32 For more on this see Pitulescu, 114-20.

33 Costache Codrescu, ed., Armata Română în revoluţia din decembrie 1989, $2^{\text {nd }}$ rev. ed. (Bucharest: Editura Militară, 1998), 82. 
A day later, on 21 December 1989, unrest sparked in major cities throughout Romania as follows: Arad (08:00 hours); Sibiu (09:45 hours); ;4 Târgu Mureş (11:30 hours); Reşiţa (12:00 hours); Bucharest (12:40 hours); Braşov (13:00 hours):;5 Cluj (15:00 hours); and Alba Iulia (22:30 hours).$^{36}$ In Bucharest, Ceauşescu decided to organize a mass rally on that day at 12:00 hours. In his speech of 21 December 1989, the secretary general of the RCP referred to the necessity of safeguarding national sovereignty and asked for "force and unity in defending Romania's independence." While Ceauşescu was delivering his speech, people from the crowd started to yell. Shouts of "Timişoara!" were also heard. ${ }^{37}$ Totally confused, Ceauşescu tried to calm down the people from the balcony of the $\mathrm{CC}$ of the RCP, but nobody listened to him. Intended to support Ceauşescu's rule, the meeting turned into an anti-Ceauşescu demonstration. Meanwhile, gathered in the University Square, demonstrators shouted anti-Ceauşescu slogans such as: "Yesterday in Timişoara, tomorrow in the whole country!" "Down with communism!" "Freedom!" and "Death to the tyrant!" At about 14:00 hours, army units backed by armored vehicles were called to reinforce the already existing units in the area. ${ }^{38}$ Around 22:30 hours, the protesters erected a barricade across the Bălcescu Boulevard, which was dismantled with the help of the tanks towards 23:30 hours. A bloody repression started at about 23:00 hours on 21 December and lasted until 03:00 hours on 22 December. ${ }^{39}$ All in all, 1,245 individuals were arrested, 462 wounded, and 50 killed in Bucharest on 21 December 1989.40

On 22 December, beginning with 09:00 hours, large crowds poured into the streets and made their way towards the center of the city. Once arrived in the Palace Square, the crowds assaulted the building of the CC of the RCP. Surprisingly, they faced no opposition: not a single shot was fired at the protesters. Frightened and confused, the supreme leader of the RCP, who had spent the night inside the CC building accompanied by his wife, flew by helicopter from the upper platform of the building. The communist regime broke down the very moment when Ceauşescu and his wife, Elena, flew by helicopter from the upper platform of the building of the $\mathrm{CC}$ of the RCP. The exact time was 12:08 hours on 22 December $1989 .{ }^{41}$

Outcome. As already discussed in the section on the political culture approach to the study of the 1989 regime change in Romania, no organized opposition or structured dissident movement emerged during the 1980s. Equally important, no relevant faction of soft-liners emerged within the ranks of the communist party during the same period. These issues pertain the specific features of regime and community political cultures and led to the paradocxical outcome of the 1989 revolution in Romania: the bloody revolution which brought down the communist regime brought to power the second- and third-rank members of the communist power elite. In the absence of an organized opposition to the communist regime and of a significant faction of soft-liners to pave the way to a nonviolent systemic change in December

\footnotetext{
34 On the events in Sibiu see Constantin Vasile, Noi am fost teroriştii?! (Sibiu: Editura Sibguard, 1995), 16-56.

35 Marius Petraşcu et al., Un pas spre libertate: Braşov, decembrie 1989 (Braşov: Fundaţia "Sfântul Ioan,” n.d.), 80-85.

36 Mioc, ed., Revoluţia, fără mistere, 220.

37 Codrescu, ed., Armata Română în revoluţia din decembrie 1989, 111.

38 Pitulescu, 169.

39 Stelian Tănase, "Solstiţiu însângerat la Bucureşti," in idem, Şocuri şi crize (Bucharest: Editura Staff, 1993), 14-15.

40 Pitulescu, 175.

41 Tiberiu Urdăreanu, 1989: Martor şi participant (Bucharest: Editura Militară, 1996), 115.
} 
1989, those who learned politics by doing it managed to rise to power. Thus, the second- and third-rank communist bureaucrats tactfully filled the power vacuum on 22 December 1989 in the afternoon. As already mentioned, in Romania the break with the communist past was not only non-negotiated, that is, was not based on the roundtable principle that characterized the Polish or Hungarian regime changes, but was also violent. In spite of the blood spilled in December 1989 Romania's exit from communism was perceived by many as being the least radical in ECE because of continuity between the pre- and post-1989 regimes in terms of political elite recruitment.

In the evening of 22 December 1989, an umbrella organization named the National Salvation Front - NSF (Frontul Salvării Naţionale) was established as the new ruling body with the clear mission to lead the country until the first free elections. NSF was an ad-hoc group with a very diverse membership, ranging from marginalized apparatchiks and technocrats close to the defunct communist party to nonaligned critical intellectuals and radical dissidents. ${ }^{42}$ Some of the names on the NSF list were known to the average Romanian from the programs of Radio Free Europe and other western broadcasting agencies as individuals who opposed at some point the policies of the former dictator. However, the unity of such a heterogeneous group of individuals faded away rapidly after 22 December. It became clear soon that the group of former apparatchiks gathered around Ion Iliescu was the most active and skilled in establishing and filling the new power structures. When reading the proclamation of 22 December 1989 regarding the future of post-communist Romania, Iliescu modestly put himself the last on the list of signatories ${ }^{43}$ However, once FSN was in control of state institutions, including the national TV and radio stations, it declared itself on 23 January 1990 a political party heading for the general elections established for 20 May the same year. As a consequence, the former dissidents, unwilling to back such a maneuver destined to boost the second- and third-rank communist officials to power in post-communism, left the ruling body. ${ }^{44}$

Iliescu and the NSF built their political legitimacy on their involvement in the 1989 revolution and the removal of the ruling Ceauşescu couple from power. As a former communist official, Iliescu could claim at most that he was marginalized in the early 1970s, but not that he openly opposed the communist regime. The major argument on which Iliescu built his political legitimacy was his participation in the 1989 revolution from the afternoon of 22 December onwards. Embittered by the return to power of the second- and third-rank communist activists, public intellectuals and the emerging civil society organizations claimed that the revolution was stolen

42 For an English version of the "Communiqué of the National Salvation Front of 22 December 1989," see Robert V. Daniels, ed., A Documentary History of Communism and the World: From Revolution to Collapse (Hanover, NH: University Press of New England, 1994), 345-46.

43 In the mid-1980s, rumors spread in Romania with regard to the alleged friendship between Iliescu and the new leader in the Kremlin, Gorbachev, who had known each other from the period of university studies in Moscow. In the late 1980s, Iliescu was considered by many a possible successor of Ceauşescu.

44 Public figures such as Doina Cornea and Ana Blandiana resigned from the Council of the NSF. Large demonstrations were organized that weekend against the decision to transform the NSF into a political party, while the NSF brought its own supporters to counter-demonstrate. Doina Cornea was one of the most prominent figures of Romanian dissent. On the daring women who defied Ceauşescu's personal rule. see Cristina Petrescu, "A Genderless Protest: Women Confronting Romanian Communism," Analele Universităţii Bucureşti-Ştiinţe Politice, Vol. XVI, Nr. 2 (2014), 79-102. 
by the neo-communists. Their discourse contributed significantly to the birth of the post-communist political culture of contestation in Romania.

Paradox \#2: The number of registered victims after the collapse of the communist regime on 22 December 1989 surpasses the number of registered victims during the period 16-22 December 1989 by a ratio of about 7 to 1 .

The 1989 regime change in Romania contradicted the nonviolent nature of the regime changes in ECE. The question of bringing to justice those responsible for the many victims of December 1989 has been central to almost all public debates related to the "unsolved mysteries" of the Romanian revolution. Upon its establishment in the evening of 22 December 1989, the NSF was quick to blame Ceauşescu and his inner circle of power for the for the violence and bloodshed which accompanied the collapse of Romanian communism. Consequently, only a few questioned the decision of the NSF to apply "revolutionary justice" when Nicolae and Elena Ceauşescu were caught and put to trial. After fleeing by helicopter from the upper platform of the CC building in Bucharest on 22 December 1989 at noon, the Ceauşescus were arrested the same day in the afternoon near the city of Târgovişte, which is located some $74 \mathrm{~km}$ north of Bucharest. The two were detained for three days in a military garrison in the city. On 25 December, the national television announced that Nicolae and Elena Ceauşescu were sentenced to death by a special military court and executed by a firing squad. ${ }^{45}$

The way justice was administered by the newly established power in the case of the Ceauşescu couple raised serious doubts about its adherence to the rule-of-law principles. Foreign observers questioned the way the trial was organized and carried out, and considered it just a mock trial, a sort of cover-up meant to hamper the former general secretary of the RCP provide embarrassing details on the personal histories and the past deeds of the new ruling elite.

At the same time, the decision to proceed to the hasten execution of the Ceaussescu couple contributed heavily in legitimizing the NSF in the eyes of a majority of the population. During the 1980 s, the communist propaganda managed to personalize Ceauşescu's power to such an extent that a majority of the population identified the supreme leader of the RCP with the communist regime. Although many Romanians questioned the NSF decision to execute the Ceauşescus on Christmas Day 1989, they eventually supported the decision thinking that this would put an end to the guerilla warfare allegedly waged by Ceauşescu's loyalists against the new regime. In brief, Iliescu and the leadership of the NSF managed to convince a majority of the population that only the hasten trial and execution of the Ceauşescu couple would put an end to the violence allegedly perpetrated by the staunch supporters of the communist dictatorship. Iliescu made a strong point that because of the "terrorists," that is, Ceauşescu's loyalists, the NSF adopt the "revolutionary formula" of organizing a special military court within the garrison where the Ceauşescu couple was detained. Simply put, Iliescu argued that a formal trial was not organized because there were no conditions at the time to keep the former ruling couple in a safe place for a longer period and that "any hour of delay" would have meant more killings of innocent

45 On the trial and execution of the Ceauşescu couple, see Grigore Cartianu, Sfârşitul Ceauşeştilor: Să mori împuşcat ca un animal sălbatic (Bucharest: Adevărul Holding, 2010). 
people. ${ }^{46}$ One should nevertheless note that 1,104 individuals were killed and 3,321 wounded in the 1989 revolution; of them, 944 persons were killed and 2,214 wounded after 22 December $1989 .{ }^{47}$

Criminal punishment has been applied immediately after the regime change, but only in relation to the repression of the demonstrators in Timişoara and Bucharest, and primarily against those who were part of Ceauşescu's inner circle of power. ${ }^{48}$ It should be stressed from the outset that not one of the alleged "terrorists" who supposedly fought the revolutionary forces in December 1989 was brought to justice so far. This simple fact has reinforced the idea that in December 1989 a coup d'état hampered the popular revolt to become a true revolution, and that the NSF and its leadership used the "terrorist" threat as a diversion to consolidate their power.

Several trials took place, of which the most significant are: the "Trial of the Four;" the "Trial of the Twenty-Four Members of the Executive Political Committee (Comitetul Politic Executiv - CPEx) of the CC of RCP;" the "Trial of the Twenty-Five;" and the "Trial of Nicu Ceauşescu." Some details regarding these trials are useful for understanding the limits of the process of applying transitional criminal justice in post-1989 Romania: (1) The "Trial of the Four" involved Ceauşescu's closest collaborators: Manea Mănescu (member of the CPEx of CC of the RCP); Tudor Postelnicu (Minister of Internal Affairs and candidate member of the CPEx of CC of the RCP); Ion Dincă (Prime Deputy-Prime Minister and member of the CPEx of CC of the RCP) and Emil Bobu (member of the Secretariat of CC of the RCP and member of the CPEx of CC of the RCP). On 2 February 1990, the Bucharest Military Tribunal sentenced them to life in prison. However, after 1-3 years all four were released from prison for poor health reasons; (2) The "Trial of the Twenty-Four Members of the CPEx" was initiated on 17 September 1990, and lasted exactly 248 days. On 25 March 1991, the defendants were sentenced to a total of 34 years and 3 months in prison, individual prison terms ranging from a maximum of 5 years and 6 months to a minimum of 2 years. It should be mentioned that the charges brought against the former CPEx members were related solely to their involvement in the events of 16-22 December 1989. On 20 April 1992, the Supreme Court of Justice allowed the appeal formulated by the General Prosecutor of Romania and the members of the former CPEx were sentenced to a total of 255 years in prison, with individual prison terms ranging from 8 to 16 years. However, by the end of 1994 the overwhelming majority of those convicted were either liberated from prison on poor health reasons, or granted amnesty by President Ion Iliescu; ${ }^{49}$ (3) The "Trial of the Twenty-Five" involved 25 high-ranking communist officials, Securitate and Militia officers, including two civilians from the staff of the Bucharest Crematorium. On 9 December 1991, the Military Section of the Supreme Court of Justice found them guilty, among others, of repressing the demonstrations in Timişoara on 16-18 December 1989 and for organizing a cover-up operation involving the stealing of 40 corpses of assassinated demonstrators, which were transported to Bucharest and cremated at the Bu-

46 For Iliescu's statement, see Ion Iliescu and Vladimir Tismăneanu, Marele şoc din finalul unui secol scurt: Ion Iliescu în dialog cu Vladimir Tismăneanu (Bucharest: Editura Enciclopedică, 2004), 193-96.

47 Stan Stoica, România, 1989-2005: O istorie cronologică (Bucharest: Editura Meronia, 2005), 19.

48 For more on transitional criminal justice in Romania, see Raluca Grosescu and Raluca Ursachi, Justiţia penală de tranziţie: De la Nürnberg la postcomunismul românesc (Iaşi: Editura Polirom, 2009), esp. 109-212.

49 Domniţa Ştefănescu, Cinci ani din istoria României: O cronologie a evenimentelor, decembrie 1989 - decembrie 1994 (Bucharest: Editura Maşina de Scris, 1995), 99, 134-36, 192, 219 and 375. 
charest crematorium. They were given different terms in prison; (4) The trial of Nicu Ceauşescu (1951-1996). The Ceauşescu couple had two sons, Nicu and Valentin, and a daughter, Zoe; of them, only Nicu became involved in politics and there were consistent rumors during the 1980s that he was chosen as the supreme leader's heir. In the aftermath of the 1989 regime change, Nicu Ceauşescu was put on trial and, on 21 September 1990, the Bucharest Military Tribunal charged him with incitation to murder and sentenced him to 20 years in prison. He was released from prison in 1992 for poor health reasons and died in $1996 .^{50}$

In April 2019, the Prosecutor General of Romania, Augustin Lazăr made an official statement on the completion of the so-called "File of the Romanian Revolution." On 8 April 2019, Lazăr declared that the file, which comprised some 3,330 volumes was finalized and sent to the court. Almost thirty years after the events, only three individuals have been eventually indicted in the file of the 1989 revolution: Ion Ilies$\mathrm{cu}$, former head of the NSF; Gelu Voican Voiculescu, member of the NSF and former Deputy Prime Minister; and Iosif Rus, former Commander-in-Chief of the Military Aviation. ${ }^{51}$ Although no final verdict has been reached yet with regard to any of the individuals indicted, the general feeling is that it took so long to send the file to the court because powerful individuals wanted to obscure evidence on the diversion organized by the NSF leadership after 22 December 1989.

\section{Paradox \#3: Although Romania went through one of the longest and most painful transitions to democracy in ECE, the country has not experienced so far an author- itarian backsliding after the year 2010 on the Central European model (especially the cases of Hungary and Poland).}

This author contends that the main legacy of the bloody revolution of December 1989 in Romania is the birth of a modern political culture of contestation. Such a political (sub)culture, the argument further reads, was born of the contested revolutionary character of the 1989 regime change in Romania and developed in a convoluted way through several waves of bottom-up mobilization. What many believed to be a failure of the process of democratic consolidation, that is, the recurrent negation of the revolutionary nature of a series of events which claimed the lives of over 1,100 people, ultimately proved to be the major achievement of the bloody regime change. As shown above, the revolution of 1989 brought to power a group of reform communists and not the representatives of the democratic anti-communist opposition, which contributed to the emergence of the first wave of contestation of the newly established power elite. Major segments of the educated urban strata, which represented the nuclei of the emerging civil society, constantly engaged in street protests

50 On the political careers of the CPEx members see Florica Dobre, ed., Membrii C.C. al P.C.R., 1945-1989: Dicţionar (Bucharest: Editura Enciclopedică, 2004) and Stelian Neagoe, Istoria guvernelor României, 18591995 (Bucharest: Editura Machiavelli, 1995), 230-43. On the sentences pronounced in the "Trial of the Four" and the "Trial of Nicu Ceauşescu," see Stoica, România, 1989-2005, 23 and 29. On the trials related to the repression of the 1989 revolution in Timişoara see Marius Mioc, Procesele Revoluţiei din Timişoara, 1989: Documente istorice (Timişoara: Art Press, 2004).

51 Vladimir Ionescu, "După 30 de ani: Dosarul Revoluției a fost finalizat și este trimis în instanță - cu doar 3 inculpați," CursDeGuvernare.ro, 8 April 2019: https://cursdeguvernare.ro/dupa-30-de-ani-dosarul-revolutiei-afost-finalizat-si-este-trimis-in-instanta.html; accessed on 10 July 2020. 
against the "neo-communist" power and supported initiatives aimed at dealing with the wrongdoings of the defunct communist regime.

The political culture of contestation mentioned above was born of several successive waves of bottom-up mobilization, of which the first occurred in early $1990 . .^{52}$ The event which epitomizes the emergence of the first pro-democracy wave of mobilization is undoubtedly the issuance of the "Proclamation of Timişoara." The Proclamation was issued on 11 March 1990 in the city which sparked the 1989 revolution and its Article 8 requested the banning of all former nomenklatura members, party activists, and officers of the former secret police from running in the next three elections. ${ }^{53}$ Article 8 of the "Proclamation of Timişoara" opened practically the debate over lustration in post-communist Romania. Demonstrations against the NSF and its leader, Iliescu, continued and culminated with the occupation of the center of Bucharest on 22 April 1990. The area occupied by the demonstrators was declared the first "area free of neo-communism" and the round-the-clock protest, which lasted for almost two months, has been known since as the University Square phenomenon. Among others, the University Square demonstrators asked for the introduction of lustration legislation and the application of Article 8 of the "Proclamation of Timişoara." The University Square phenomenon ended sadly, in violence and bloodshed, on 13-15 June 1990. Beginning with 13 June, the police and special troops, as well as workers from Bucharest's industrial platform and Jiu Valley miners, brought to Bucharest by train, brutally attacked the demonstrators in the University Square. ${ }^{54}$

The power shift of 1996 created a favorable context for the further development of the culture of contestation born in the aftermath of the 1989 revolution. The second wave of contestation, however, shifted its focus from the "neo-communist" power to the thorny issue of opening the files of the former communist secret police, the infamous Securitate. The united center-right opposition managed to win the 1996 elections, but was quite slow to initiate a comprehensive process of dealing with the wrongdoings of the communist regime. This center-right coalition was also undermined by numerous inner conflicts, and eventually disintegrated before the general elections of the year 2000. Consequently. Ion Iliescu returned to power together with his party, which reinvented itself a year later as the Social-Democratic Party - SDP (Partidul Social Democrat). A new power shift occurred in 2004, when PSD lost power and the Alliance "Justice and Truth" - JT (Dreptate şi Adevăr) came to power. The JT alliance was composed of the Democratic Party - DP (Partidul Democrat), which shifted in the meantime from center-left to center-right politics, and the "historic" National Liberal Party - NLP (Partidul National Liberal). In 2007, the JT alliance broke apart after the DP left the government. Subsequently, the DP merged with a rump faction of its former ally NLP and formed the Democratic Liberal Party - DLP (Partidul Democrat Liberal). The DLP won the parliamentary elections of 2008, while the presidential elections of 2009 were won by Traian Băsescu, who had already served one term in office as president over the period 2004-2009. Băsescu,

52 For an approach to mass mobilization focusing on three phenomena, that is, origins, protest and outcome, see Doron Shultziner and Sarah Goldberg, "The stages of mass mobilization: separate phenomena and distinct causal mechanisms," Journal for the Theory of Social Behaviour, Vol. 49, Issue 1 (2019): 2-23.

53 See Annex 2: "Proclamaţia de la Timişoara," in Ştefănescu, Cinci ani din istoria României, 453-54.

54 On the political instrumentation of the communist past in post-communist Romania, including an analysis of the University Square phenomenon, see Alexandru Gussi, La Roumanie face à son passé communiste: Mémoires et cultures politiques (Paris: Editions de l'Harmattan, 2011). 
who was the presidential candidate of the DLP, won the presidential elections with a very slight margin.

During the first presidential mandate of Băsescu (2004-2009), a significant part of the electorate proved to be sensitive to the dividing line between anti-communism and neo-communism in Romanian politics. In 2005, the bulk of the Securitate files were transferred to the National Council for the Study of the Securitate Archives (CNSAS) and in December 2006 President Băsescu officially condemned the abuses of the communist dictatorship in Romania in front of the Parliament. Beginning in 2009, the anti-communist versus neo-communist debate in politics, as well as in public discourses, gradually faded away. Neo-communism, as a marker of authoritarian propensities and anti-communism. as a marker of democratic convictions lost their mobilizing power.

From the year 2009 to the present, successive waves of contestation were prompted by decisions by the power elite associated with authoritarian backsliding, as well as by key public issues such as: political corruption, environmental problems, acceleration of motorways construction, police violence and incompetence by the local authorities and law enforcement agencies..$^{55} \mathrm{~A}$ most creative, though highly offensive campaign, known as "mu*e SDP" was conducted from below through concrete actions and social media venues in the summer of 2018 as a powerful protest from below against the attacks of the center-left populist government on the independence of the judiciary. ${ }^{56}$ A thorough analysis of these protests would go much beyond the scope of this paper. However, it is important to note that identity-based political initiatives never caught the attention of a majority of the population and thus were not able to mobilize large segments of the ethnic majority. As shown above, social-identity politics also failed to mobilize the most active segments of the population, not to speak of the Romanian diaspora. An element of novelty in post-2010 politics is the growing implication of the Romanian diaspora, which lately began to act as a transnational diaspora, in the process of democratic consolidation. This a clear sign that civil society in Romania has entered a mature stage of development. In the following, the analysis will focus on the period 2016-19 and the populist policies adopted by the center-left government simultaneously with attacks on the judiciary - which can be associated with attempts at authoritarian backsliding, as well as on societal responses to these policies.

After 2010, identity politics mobilized electorates throughout ECE. Interestingly enough, one can identify conspicuously similarities between right-wing and left-

55 The most notable street protests in this respect were: (1) mass protests against attempts by the government to decriminalize official misconduct related to corruption offences in January-February 2017; (2) the anti-government protest organized by members of the Romanian diaspora in Bucharest in August 2018; and (3) protests against the incompetence of the law enforcement institutions following a gruesome murder case in July 2019. See: Euronews, "Protesters in Romania hold huge demonstration over government ,anti-corruption U-turn,"” 2 February 2017; Claudia Ciobanu, "Migrants left for a better life. Now they fight for a better Romania," The Guardian, 22 August 2018; and "Suspect confesses to killing Romanian teenagers as anger grows at police," The Guardian, 28 July 2019; the articles quoted above are available at the following links:

https:/www.euronews.com/2017/02/02/protesters-in-romania-hold-huge-demonstration-over-government-anti-corruption-u; https://www.theguardian.com/commentisfree/2018/aug/22/romania-migrant-diaspora-protest-police-crackdown-corruption; https://www.theguardian.com/world/2019/jul/28/thousands-protest-romania-police-child-kidnapping-murder; accessed 9 July 2020.

56 This highly creative and ironic campaign was centered on very offensive four-letter word, which refers to oral sex. See, for instance, Răzvan Băltărețu, "Aproape toate modurile în care PSD și-a luat mu*e de la români. Mesajul ăsta s-a întins ca focul și a adunat în spatele lui tot ce au încercat românii să spună prin proteste, prin vot sau prin alte demersuri,“ 22 July 2018; https://www.vice.com/ro/article/vbjv5y/feluri-muie-psd-de-la-romani; accessed 9 July 2020. 
wing populism in ECE. In the following, the analysis will focus on three dimensions of populist policies, which scholarly literature has identified as central in the cases of Hungary and Poland, as follows: (1) emphasis on the nation, united and undivided, as a political community; (2) popular sovereignty as key political principle; and (3) legal resentment, that is, a tendency to shift from rule of law to rule by law. ${ }^{57}$

In the case of Romania, one should mention that the communist successor party, the SDP has been in power since 2012. The SDP had three leaders during the period under scrutiny (2012-2019): Victor Ponta (2010-2015), who also served as Prime Minister during the period May 2012 - November 2015; Liviu Dragnea (2015 to May 2019 - when he was definitively sentenced to three years and six months in prison), who also served as President of Chamber of Deputies of the Romanian Parliament (December 2016 - May 2019); and Viorica Dăncilă (May 2019 - November 2019), who also served as Prime Minister (the first woman who held this post) during the period January 2018 - November 2019.

In terms of popular sovereignty two issues deserve further examination: (a) the anti-EU rhetoric of the post-2016 SDP power elite and the successive cabinets formed by SDP; and (b) the issue of "populist constitutionalism," which in the case of SDP refers to the almost full control of the Constitutional Court in the post-2016 period, with no major attempts at changing the Romanian Constitution (except for the failed referendum for defining the traditional family held on 6 and 7 October 2018). Legal resentment, in the case of Romania, is primarily related to the post2016 period and especially to the attack on the National Anti-Corruption Directorate and its head, Laura Codruţa Kövesi (appointed in 2013 and dismissed in 2018) and on the attempts at changing the current anti-corruption legislation. ${ }^{58}$ These attacks have been linked to the suspended two-year sentence the SDP leader Dragnea received in April 2016 for electoral fraud. In this respect, a leader of an opposition political party aptly put it: "The government and the SDP have blown up the justice system in order to save Liviu Dragnea" (Dan Barna, leader of the opposition party Save Romania Union - SRU). ${ }^{59}$ In the end, these attacks on the legal system did not bear fruit, since the SDP leader was definitively sentenced in May 2019 to three years and six months in prison and currently serves the prison term. ${ }^{60}$

57 Popular sovereignty and legal resentment are defined following Paul Blokker's analysis of the four major dimensions of the populist critique of liberalism: (1) popular sovereignty as the key justificatory claim of populism; (2) majority rule as the main mode of government as identified by populists; (3) instrumentalism as the predominant approach of populists in engaging with public law; and (4) legal resentment as the populists' main attitude towards public law. Paul Blokker, "Populism as a Constitutional Project," International Journal of Constitutional Law, Volume 17, Issue 2, April 2019, 536-553. Regarding authoritarian backsliding in Hungary and Poland, see for instance András Bozóki, "Broken Democracy, Predatory State and Nationalist Populism," in Péter Krasztev and Jon Van Til, eds., The Hungarian Patient: Social Opposition to an Illiberal Democracy (Budapest: CEU Press, 2015), 3; and Joanna Fomina and Jacek Kucharczyk, "Populism and Protest in Poland," Journal of Democracy, Volume 27, Number 4 (October 2016), 58.

58 In the meantime, Kövesi was appointed in October 2019 as the first European chief prosecutor, on a seven-year mandate, as head of the new European Public Prosecutor's Office (EPPO). See RFE/RL's Romanian Service, "Romania's Koevesi Confirmed as EU Top Prosecutor," 16 October 2019; https://www.rferl.org/a/koevesi-confirmed-as-eu-top-prosecutor/30220304.html; accessed on 9 July 2020.

59 Craig Turp, "Romanian government launches new attack on justice system," Emerging Europe, 19 October 2018; https://emerging-europe.com/news/romanian-government-launches-new-attack-on-justice-system/; accessed on 9 July 2020.

60 "Romania corruption: PSD chief Liviu Dragnea jailed,” BBC News, 27 May 2019; https://www.bbc.com/news/ world-europe-48421430; accessed on 9 July 2020. 
As a communist successor party, SDP has inherited from the ideology of national-communism, as developed by the former RCP after 1968, the idea of the four "pillars" of Romanian history, that is: (1) ancient roots; (2) continuity; (3) unity and (4) struggle for independence. For the RCP power elite, these elements represented historical truths and not historical myths developed in the second half of the 19th century. ${ }^{61}$ Moreover, the systematic public exposure of the wrongdoings of the communist regime through the opening of the Securitate files after 2005 left little usable past to be politicized by the SDP. True, a mild nostalgia for the "golden period" of Ceauşescu's communism 1965-77 did emerge in Romania in the context of the global financial crisis of 2008, but this type of nostalgia had no restorative aspects.

This is not to say that SDP has not tried to politicize the Romanian identity in an attempt at combining ethno-cultural and social identity politics. On the contrary, there were at least three major moments which proved that the Romanian population was not mobilized by SDP's recourse to nationalism: (1) Victor Ponta's (failed) presidential campaign of 2014 under the slogan Mândru că sunt român! (Proud of being Romanian!); ${ }^{62}$ (2) the (failed) referendum for the "traditional" family, ${ }^{63}$ and (3) the underwhelming celebration throughout 2018 of 100 years from the 1918 unification of Transylvania with the Old Kingdom of Romania - which was marked, as a reputed journalist puts it, by "counter performance and institutional mediocrity."64

Given the obvious failure to capitalize on Romanian identity and history, SDP has engaged in a campaign of politicizing social benefits for state employees and pensioners. Salaries and pensions, including a growing number of special state pensions have been raised and put a heavy burden on the state budget. Government officials present almost weekly initiatives meant at raising salaries in the state sector and state pensions. ${ }^{65}$ Nevertheless, this did not help the ruling SDP to win the EU elections in May 2019. More importantly, the SDP leader and Romanian Prime Minister Viorica Dăncilă lost the presidential elections of November 2019 to the acting President Klaus Iohannis, who won a second mandate. ${ }^{66}$ Romanian voters sanctioned the political decisions by the SDP power elite which have been largely associated with authoritarian backsliding. This is also supported by the results of the referendum called by President Iohannis on two issues concerning the judiciary, which indicated that an

${ }^{61}$ For more on this, see Cristina Petrescu, "Historiography of Nation-Building in Communist Romania," in Pavel Kolář and Miloš Rezník, eds., Historische Nationsforschung im geteilten Europa, 1945-1989 (Cologne: SH Verlag, 2012), 153-65.

62 Victor Ponta, Facebook; https://www.facebook.com/victor.ponta/photos /a.664236270282930.1073741966.150967671609795/66423631028292/_https://ro-ro.facebook.com/ victor.ponta/photos/am-lansat-aplicatia-mandru-ca-sunt-romanva-provocam-sa-publicati-pe-pagina-defa/748139738559249/; accessed on 9 July 2020.

63 Kit Gillet, "Romania: Conservatives Wanted Voters to Limit Definition of 'Family.' They Failed," The New York Times, 7 October 2018; https://www.nytimes.com/2018/10/07/world/europe/romania-referendum-marriage.html; accessed on 9 July 2020.

64 Cristian Pătrăşconiu, "Centenarul Marii Uniri prin lentila lucidității patriotice," Puterea a cincea, 11 October 2018; https://putereaacincea.ro/centenarul-marii-uniri-prin-lentila-luciditatii-patriotice/; accessed on 9 July 2020.

65 "Pensiile speciale în România: Aproape zece mii de beneficiari, fără a lua în calcul militarii și polițiștii/ Pensii medii de peste 17.000 de lei," G4 media.ro; https://www.g4media.ro/pensiile-speciale-in-romania-aproapezece-mii-de-beneficiari-fara-a-lua-in-calcul-militarii-si-politistii-pensii-medii-de-peste-17-000-de-lei.html; accessed on 9 July 2020.

66 France24, "Pro-European incumbent wins Romania presidential elections," 24 November 2019; https://www.france24.com/en/20191124-pro-european-incumbent-wins-romania-presidential-elections; cessed on 9 July 2020. 
overwhelming majority of the population has perceived negatively the SDP attempts at restricting the independence of the judiciary. ${ }^{67}$ In contradistinction to Romania, the ruling Fidesz and PiS parties in Hungary and Poland comfortably won the EU elections. ${ }^{68}$ Looking to Romanian politics in the midst of the global pandemic provoked by the COVID-19 virus it seems that a populist consensus was not reached so far. In spite of consistent attempts at authoritarian backsliding over the period 2016-19, the process of democratic consolidation continues in Romania, albeit slowly.

\section{Concluding remarks}

This study has set forth three political paradoxes which characterize the 1989 regime change in Romania and the thirty-year period, that is, 1989-2019 which elapsed from those events. As shown above, to explain the 1989 regime change in Romania this author has explored the aggregation of structural (common to all), conjunctural and nation-specific factors. In Romania, the argument further reads, the 1989 regime change was not only violent, but also heavily contested afterwards because of the return to power of second- and third-rank communist officials and, more importantly, because of the significant number of victims registered after the breakdown of the Ceauşescu regime on 22 December 1989 at noon. This situation led to the birth of a political (sub)culture of contestation among the educated urban strata of society, which matured and expanded through several waves of bottom-up mobilization. This also led to the emergence of a transnational diaspora, increasingly involved in supporting democratic consolidation back home.

This author contends that the main legacy of the violent and contested 1989 revolution in Romania was exactly the development of such a political (sub)culture of contestation. A major outcome of the set of attitudinal and behavioral patterns developed in the thirty-year period which folloed the 1989 events is that Romania has not experienced so far authoritarian backsliding on the Central European model, as one could witness in Hungary and Poland in the post-2010 period. A major feature of the populist policies which led to authoritarian backsliding in Hungary and Poland has been identity politics. This study has identified and analyzed, in the Romanian case, the key elements of the Central European populist vision of politics as follows: (1) emphasis on the nation, united and undivided, as a political community and on politicization of history; (2) popular sovereignty as key political principle; and (3) legal resentment, that is, a tendency to shift from rule of law to rule by law. In Hungary and Poland, all these three elements have been successfully translated into political action, while in Romania the attempts at capitalizing on politicization of national history and ethnic identity failed for the time being.

\footnotetext{
67 Mădălin Necsutu, "Romania Justice Referendum Deals Blow to Ruling Party,” BalkanInsight, 27 May 2019 ; https://balkaninsight.com/2019/05/27/romania-justice-referendum-deals-blow-to-ruling-party/; accessed on 9 July 2020.

68 European Parliament, “2019 European election results;” https://election-results.eu; accessed on 9 July 2020.
} 